\title{
Determinants of Small-scale Fishermen's Income on Oman's Batinah Coast
}

\author{
OMAR AL JABRI, RAY COLLINS, XIMING SUN, ABDALLAH OMEZZINE, and RAKESH BELWAL
}

\section{Introduction}

The small-scale fisheries sector in the Sultanate of Oman is not only an important source of seafood for consumers, but it is also a major social and economic contributor to the Sultanate. Almost 90 percent of Oman's total marine fishery production is provided by the small-scale fisheries sector (MAF, 2010). For decades, this sector has been the main supplier of fish for Omani households and exports.

Omar Al-Jabri is Assistant Professor, Department of Natural Resource Economics, Sultan Qaboos University, P.O. Box 34 Al Khoudh, P.C. 123, Sultanate of Oman. Ray Collins is Professor of Agribusiness, University of Queensland, Gatton Campus, Building 8117a, Gatton, QLD 4343, Australia. Ximing Sun is Research Fellow, University of Queensland, Gatton Campus, Building 8117a, Gatton, QLD 4343, Australia. Abdallah Omezzine is Professor and Vice Chancellor for Postgraduate Studies and Research, University of Nizwa, P.O. Box 33, PC 616, Berkat al Mouz, Sultanate of Oman, and Rakesh Belwal (corresponding author) is Associate Professor, Faculty of Business, Sohar University, P.O. Box 44, P.C. 311, Sultanate of Oman (mail: rbelwal@soharuni. edu.om).

doi: dx.doi.org/10.7755/MFR.75.3.3
The Batinah Governorates ${ }^{1}$, North and South, constitute the largest populated region in Oman and are home to about 28 percent of the national population (MONE, 2010). The Batinah coast comprises the northern coastal strip along the Gulf of Oman and is considered to be the main agricultural region in Oman (A1-Oufi et al., 2000). The coast runs for a distance of 270 $\mathrm{km}$ from "Khatmat al Malaha" in the north to As-Seeb, in the south. The coastal plain ranges from 15 to $80 \mathrm{~km}$ in width.

There are eight coastal Wilayat ${ }^{2}$ in Batinah, namely, Barka, Masana'a, Suwaiq, Khabora, Saham, Sohar, Liwa, and Shinas (Fig. 1). Each Wilayat in Oman has a Fisheries Development Centre (FDC) under the Ministry of Agriculture and Fisheries (MAF). The FDC is responsible for agricultural and fisheries extension activities in the Wilayat by providing extension services to farmers and fishermen through extension agents who are trained to

${ }^{1}$ In this paper, both Governorates will be referred to as Batinah

${ }^{2}$ Wilayah is a State within the Governorate. The plural is Wilayat (see http://en.wikipedia.org/ wiki/Wilayah)
Acronyms used in this paper.

\begin{tabular}{ll}
\hline MAF & Ministry of Agriculture and Fisheries \\
MONE & Ministry of National Economy \\
R\&D & Research and Development \\
FDC & Fisheries Development Centre \\
OMR & Omani Rial (1USD = OMR 0.3845) \\
\hline & \\
\hline &
\end{tabular}

communicate with the fishermen and to advise them.

This research required the collection of data from eight coastal Wilayat. There are more than 120 scattered villages along the Batinah coast distributed nonhomogeneously with respect to the number of fishermen in each village (Al-Oufi, 1999). All of these villages are not "fishing villages" in toto, but fishermen are mostly located in villages along the shore, thereby forming communities of their own. Some villages have a higher number of fishermen than others (Al-Oufi, 1999).

About 28 percent of the country's small-scale fishermen ply their trade along the Batinah coast. The number of Omani small-scale fishermen in 2010 was estimated at 36,320 (MAF, 2010), with 66 percent working fulltime in this profession (MAF, 2010).
ABSTRACT-The small-scale fishing industry of Oman is responsible for almost 90 percent of the total marine fishery production. It is also the main supplier of fish for Omani households. This study analyzes the factors that determine small-scale fishermen's income on Oman's Batinah Coast, which has almost 30 percent of Oman's population and more than one-third of the small-scale fishermen. We find that fishermen's income here can be explained broadly under four major blocks of variables: geographical region, fishing inputs and catch, socioeconomic and demographic characteristics, and the nature of the relationship with fisheries extension services.

In general, the Wilayat (local administrative units) failed to make any significant impact on fishermen's income. The variable "Fishing inputs and catch," such as increases in engine power, boat length, weekly catch, and number of weekly trips, positively impacted fishermen's income while increases in weekly fishing costs, number of crew members, and difficulty in getting ice had a significantly negative effect on the in- come. Furthermore, socioeconomic and demographic characteristics also contributed significantly in determining the fishermen's income level. The other important findings were related to extension services. The variables "Fishermen's exchange of information and cooperation with the ministry" and "Fishermen's involvement in the extension activities" were found to have positive effects on fishermen's income levels. Capitalizing on these findings could improve fishermen's incomes and their lives across the region, as well as nationally. 


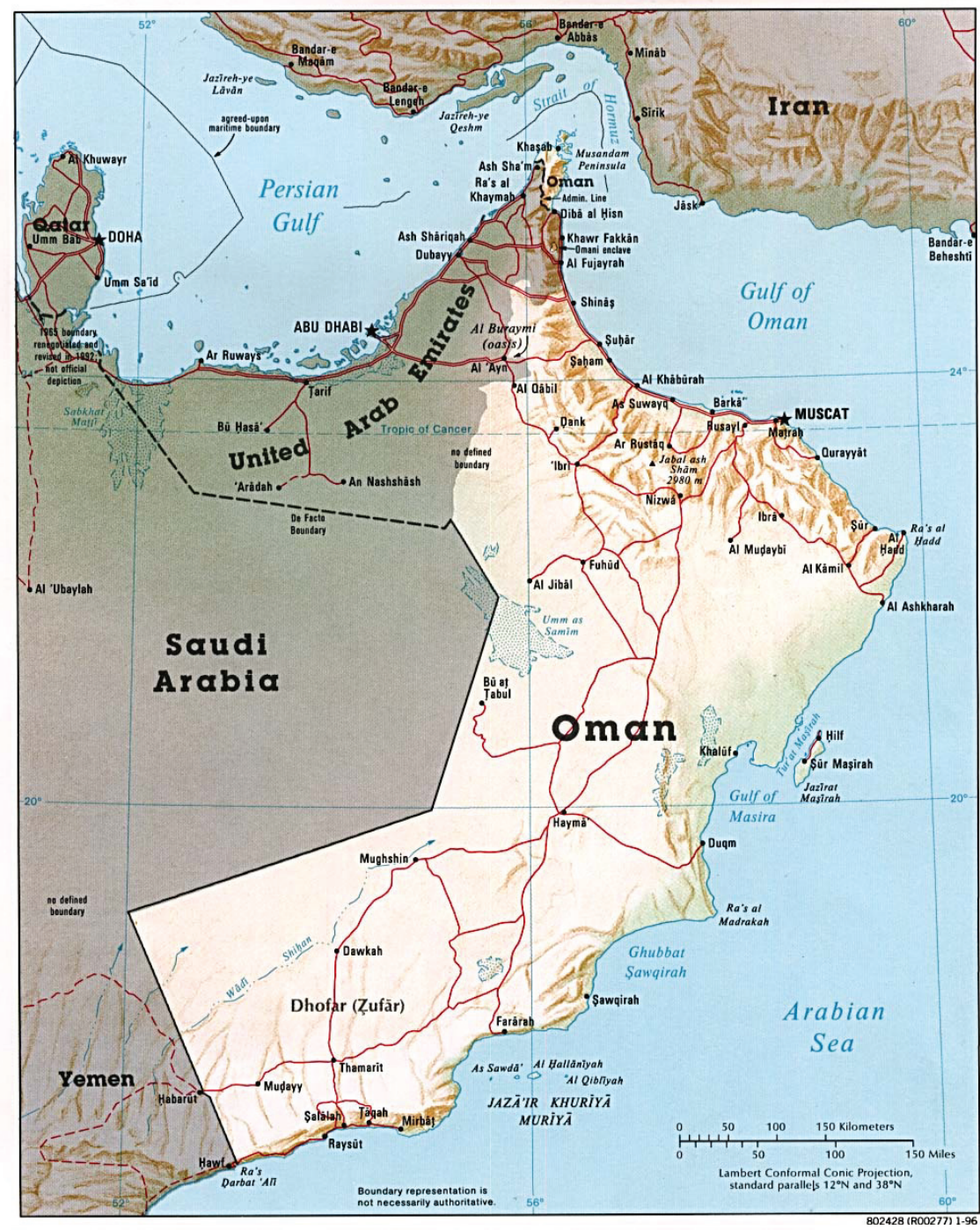

Figure 1.-Oman's Batinah coast: the northern coastal strip along the Gulf of Oman. (Source: http://athaia.org/oman-map.html oman_relief.jpg).

Statistical data (MAF, 2010) reveals that around 40 percent of Batinah fishermen reside in the southern Wilayat of Barka, Masana'a, and Suwaiq, while the remaining 60 percent reside in the northern Wilayat of Shinas, Liwa, Sohar, Saham, and Khabora. These fishermen mainly depend on the fish landings on the Batinah coast for their subsistence (Belwal et al., 2012).

Fish landings in the Batinah coast formed 15 percent of the total national landings in 2010 (MAF, 2010). While landings in the Al-Batinah region dropped by $7 \%$ in 2010 compared which only a few fishermen can afford, is shown in Figure 2. The drop in both income and landings is a serious concern to the fishermen on the Batinah coast of the Sultanate and demands interventions for their sustainability. This paper explores factors that determine fishermen's income and assesses their relative contribution in determining fishermen's income. Based on the findings and discussions, some policy implications are also put forward.

\section{Determinants of Small-scale Fishermen's Income}

Previous studies of small-scale fishermen's incomes elsewhere have been based on fishing inputs as well as socioeconomic or demographic factors (Ocheiwo, 2004; Tzanatos et al., 2006; Agimass and Mekonnen, 2011). Studies identifying factors that directly or indirectly relate to income can rarely be found in the case of Oman. These factors could be as diverse as the application of good fishing practices, knowledge gained from extension services, or the geographic location of the fishermen. Moreover, understanding the social, demographic, cultural, and economic situation in a particular area is crucial to fisheries management and planning (Villareal, 2004). Availability of four-wheel drive trucks can improve efficiency by providing good support during towing operations (Fig. 3).

A review of relevant literature indicates that fishermen's income in a region is affected by a number of factors. Such variations can arise for several reasons, such as the number of fishermen in each region, the number and distribution of the villages in each region, the sharing of the resources between regions, the nature of the seabed in different regions, fishing habits of fishermen, available fish species, offshore distance to be travelled, market infrastructure, consumer habits, equipment used in fishing, availability of ice and fuel, activities of the extension service departments, the age and experience of the fishermen, the socioeconomic conditions of fishermen, types and nature of preferred buyers, and availability of market outlets 


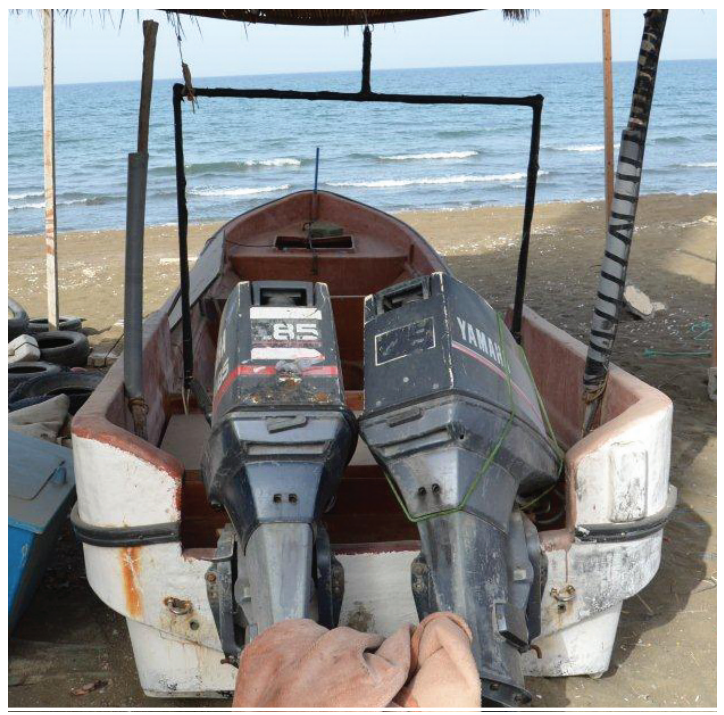

Figure 2.-A typical two-engine fiberglass boat used on the Batinah Coast.

(Ocheiwo, 2004; Tzanatos et al., 2006; Belwal et al., 2012). Alhabsi (2012) observes that the level of income of the fishermen on the Batinah coast of Oman depends on the fishing gear that they use and the region where they fish. According to her, the fishermen who used beach seine and encircling nets belonged to a higher income category than those who used lines and traps. According to Alhabsi (2012), the majority of the low income fishermen belonged to the Shinas and Liwa regions of the Batinah coast.

An understanding of the determinants of income can help in identifying policies and practices for sustaining fishermen's livelihoods, and thereby in conserving the fishing communities. Positing variables (particularly regional ones), fishing inputs and catch, socio-economic and demographic factors, and extension and $\mathrm{R} \& \mathrm{D}$ activities as the major determinants or independent factors, this study attempts to assess fishermen's income as the dependent variable. The study also assesses the relative contribution of these factors and subfactors in determining income. However, the variables affecting fishing output or income can be as diverse as household size, the gender of fisherman, fishing experience, season, fishing craft, labor, conditions, landing of fish, and demand for fish) cannot. Davis (2012) finds that fishermen are constantly faced with making decisions where the financial gain or loss is highly uncertain, such as the choice of species to fish, type of gear to use, and optimal fishing location. His findings indicate that there is some relationship between these decisions and fishermen's income. According to Degen et al. (2010) this specialization acts as the more effective way of improving income. Fishermen's control of these variables, termed innovative tactical behavior, helps them in maintaining income, although differences exist depending on scale and type of fishing (Christensen and Raakjær, 2006).

Furthermore, the role of demographic and socioeconomic variables (i.e., age of fishermen, literacy, relationship with crew, boat ownership, partnership in other boats, income sharing, and alternative sources of income) in determining income is important to explore. It is also important to explore the relationship between fishermen's income and their participation in the extension activities of the government. Although it has been observed that a passive attitude towards participation among fishermen's groups reduces the chances of success for fisheries regulations, whether this applies vice

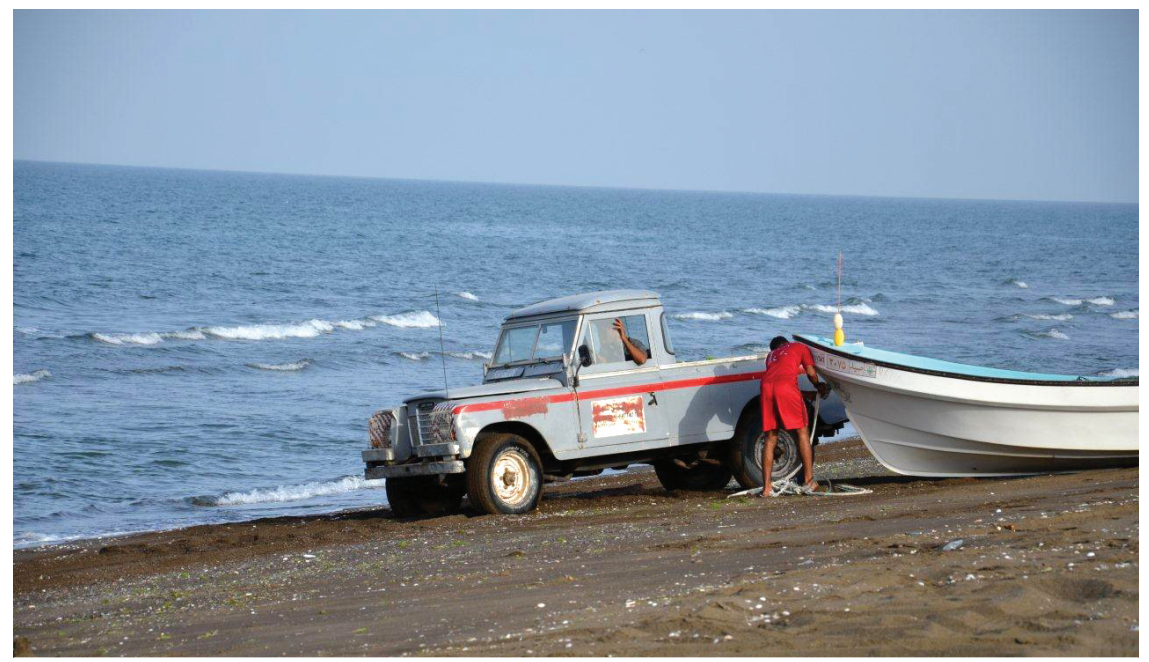

Figure 3.-Fishing inputs: use of truck in towing boats to and from the coast. 


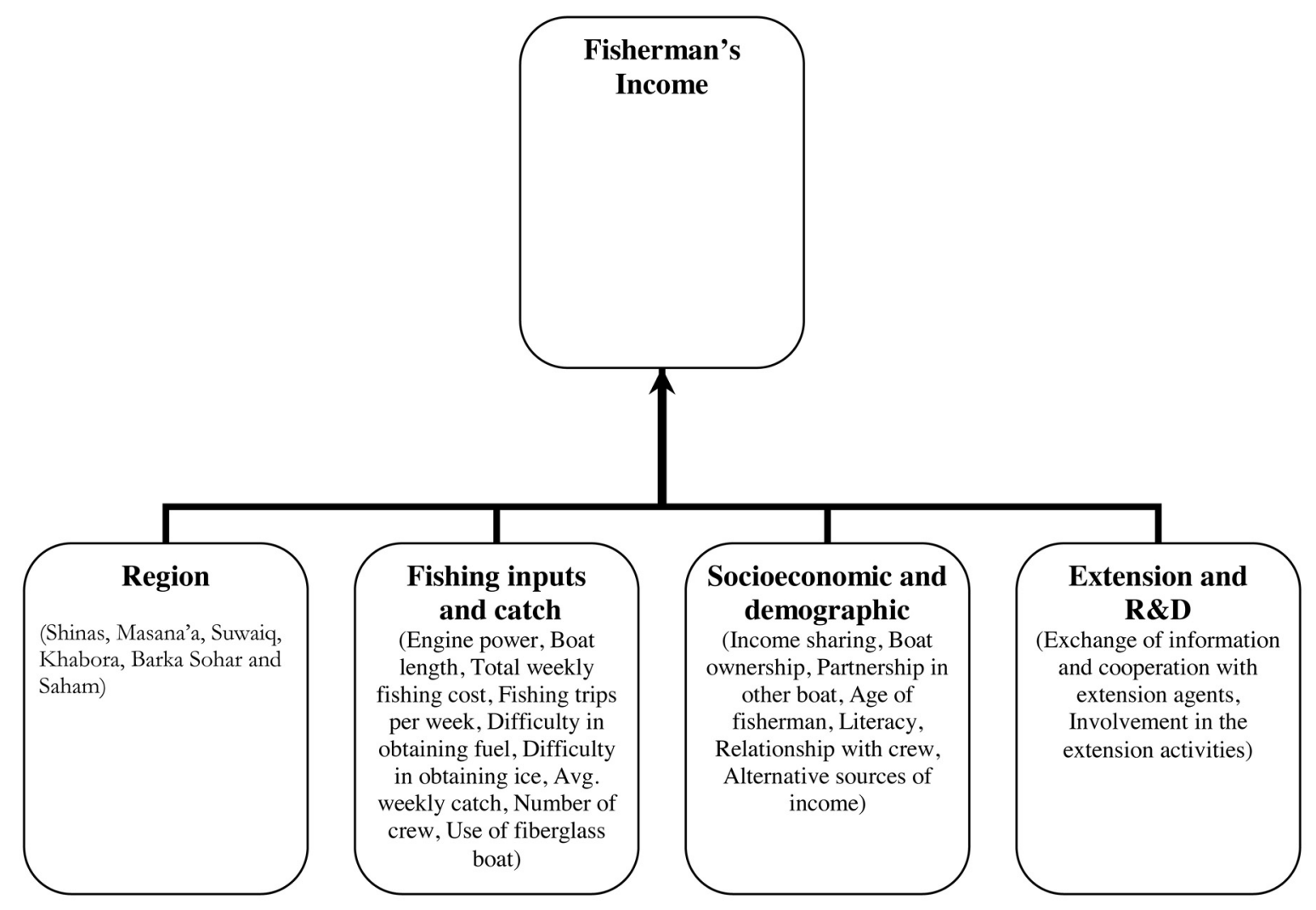

Figure 4.-Conceptual framework: determinants of a fisherman's knowledge.

versa has not been explored (Nielsen, 1992). The assumption here is that good relationships between fishermen and extension activities can lead to improved fishing practices, and therefore to greater incomes. The relationship with extension services optimizes the dissemination of new technologies, management, decision making, organizational skills, and feedback and thereby increases yield and productivity (Ahmad et al., 2007).

\section{Methodology and Measures}

In proportion to the overall population of fishermen on the Batinah coast, a sample of 510, representing approximately 5 percent of the fishermen, was drawn for collecting data. To ensure a medium to high response rate, a quota-cum-convenience sampling ${ }^{3}$

${ }^{3}$ The basic idea of quota sampling is to set a target number of completed interviews with specific subgroups of the population of interest. The was used to draw sample fishermen, in proportion to their distribution within Wilayat.

We observed "Fishermen's Income" as the key variable (dependent), which was regressed on four independent groups of variables: geographical regions, fishing inputs and catch, socioeconomic and demographic variables, and the nature of the fishermen's relationship with fisheries extension services to understand the contribution of each group to fishermen's income. The overall conceptual framework is shown in Figure 4, which has been used to develop and test a model for determining the income in this study.

sampling procedure then proceeds using a nonrandom selection mechanism until the desired number of completed interviews is obtained. We used a convenience sampling approach as a mechanism to select the respondents (See http:// srmo.sagepub.com/view/encyclopedia-of-survey-research-methods/n431.xml).
Since the dependent variable (fishermen's income) was dichotomous (high, low) and there were more than two independent variables involved, multiple logistic regression ${ }^{4}$ was carried out to assess the nature and extent of its relationship with the independent variables. Like other forms of regression analysis, multiple logistic regression is used when the dependent variable is nominal and there is more than one independent variable.

We followed a forward stepwise process of logistic regression analysis for the estimation of alternative models. Under this approach, an individual variable or groups of variables are added in a sequential manner to develop the model, and the validity of the

${ }^{4}$ Like other forms of regression analysis, multiple logistic regression is used when the dependent variable is nominal and there are more than one independent variables (see http://udel. edu/ mcdonald/statlogistic.html for a better understanding). 
Table 1.-Groups of variables for logistic regression.

\begin{tabular}{|c|c|c|c|}
\hline $\begin{array}{l}\text { Block 1: } \\
\text { Regions }\end{array}$ & $\begin{array}{l}\text { Block 2: } \\
\text { Fishing inputs } \\
\text { and catch }\end{array}$ & $\begin{array}{c}\text { Block 3: } \\
\text { Socioeconomic } \\
\text { and demographic }\end{array}$ & $\begin{array}{c}\text { Block 4: } \\
\text { Extension and R\&D }\end{array}$ \\
\hline $\begin{array}{l}\text { Wilayat (Shinas, } \\
\text { Masana'a, Suwaiq, } \\
\text { Khabora, Barka } \\
\text { Sohar, and Saham) }\end{array}$ & $\begin{array}{l}\text { Engine power } \\
\text { Boat length } \\
\text { Total weekly fishing cost } \\
\text { Fishing trips per week } \\
\text { Difficulty in obtaining fuel } \\
\text { Difficulty in obtaining ice } \\
\text { Avg. weekly catch } \\
\text { Number of crew } \\
\text { Use of fiberglass boat }\end{array}$ & $\begin{array}{l}\text { Income sharing with crew } \\
\text { Ownership of boat } \\
\text { Partnership in other boat (s) } \\
\text { Fisherman's age } \\
\text { Literacy level of fishermen } \\
\text { Relationship with crew } \\
\text { Alternative source of income }\end{array}$ & $\begin{array}{l}\text { Fishermen's exchange of } \\
\text { information and cooperation with } \\
\text { extension agents (Factor A1) } \\
\text { Fishermen's involvement in the } \\
\text { extension activities (Factor A2) }\end{array}$ \\
\hline
\end{tabular}

added variables is ascertained in terms of significant improvement of the fit. Although stepwise regression is considered as a good exploratory research tool, it does not necessarily produce the best model if predictors are repetitive (Judd et al., 2008) or might produce biased regression coefficients or a high R-squared value (Tibshirani, 1996).

Since logistic regression allows prediction of the probability of the nominal variable using the odds ratio, we also predicted the likelihood of fishermen's income being high or low with an increase or decrease in a particular independent variable. The following two sections explain the operationalization of the dependent and independent variables used in this research.

\section{Measuring the Dependent Variable}

In this study, the dependent variable fishermen's income was operationalized as a binary variable having values 0 or 1 to represent the income level as low and high, respectively. Annual income equal to or below OMR 800 was assigned the 0 value, while an income above OMR 800 was assigned the value of 1 . This was mainly done in order to reduce biases, over or understatements of income, and also in recognition of the fact that fishermen are unlikely to keep records of their income. This cut-off point of OMR 800 was chosen as an amount close to the average estimated income of the fishermen on the Batinah coast, which was estimated from the collected data. Thus, a recorded annual income above OMR 800 was said to be "high" or "low" and vice-versa. This newly derived dichotomous variable was regressed against different independent variable blocks as expressed in the next section.

\section{Measuring Independent (grouped) Variables}

As mentioned, operations and outcomes of small-scale fishermen depend heavily on factors that they can control, influence, and manage. This research considers boat length and size, engine power, crew numbers, number of trips, amount of catch, gear used, and operating costs as factors that can be controlled by fishermen and which could affect their income. Furthermore, the research also explores the role of demographic and socioeconomic variables (income sharing, boat ownership, partnership in other boats, age of fisherman, literacy, relationship with crew, and alternative sources of income) in determining income.

As indicated in Table 1, Block 1 contains a single variable, "Wilayat," which represents seven ${ }^{5}$ regions on the Batinah coast. The variable "Wilayat" was a categorical variable having 7 categories (levels) and was coded using 6 (7 minus 1) dummy variables by the deviation contrast coding system. ${ }^{6}$ This coding system compares

${ }^{5}$ The respondents from Liwa being few (7) and keeping in view the proximity between Liwa and Shinas, the data were merged for the purpose of analysis and are represented as Shinas data.

${ }^{6} \mathrm{~A}$ categorical variable of $\mathrm{K}$ categories is usually entered in a regression analysis as a sequence of $\mathrm{K}-1$ variables, e.g., as a sequence of $\mathrm{K}-1$ dummy variables (see http://www.ats.ucla.edu/stat/r/library/contrast_coding.htm). the mean of the dependent variable for a given level to the overall mean of the dependent variable without any need for specifying a reference level. Hence, to fit models with categorical independent variables, we can compare how much better (or worse) each category is from the average effect. For instance, if the variable "Geographic region" has four categories A, $\mathrm{B}, \mathrm{C}$, and $\mathrm{D}$, each coefficient would reflect the minus or plus effect of living in a certain region, as compared with the overall effect which can be regarded as the average of the effects of living in the various regions. These procedures are called deviation contrasts (Hendrickx, 1999; Nichols ${ }^{7}$ ).

Block 2 contains the group of variables representing fishing inputs and catch. Fishing activities of a fisherman depend directly on factors such as boat, gear, and inputs that he possesses. Operationalization and measurement of these groups of variables are reflected in Table 2. Block 3 contains variables describing the fishermen's socioeconomic and demographic characteristics.

Block 4 includes two variables (or factors) pertaining to the fishermen's relationship with extension activities, extracted using factor-analysis. Field (2005) mentions that factor analysis reduces a dataset to a more manageable size, by retaining as much of the original information as possible, which helps in understanding the structure of data. Additionally, factor analysis is used to overcome the problems of collinearity in regression (Field, 2005). Combining variables generates a subset of uncorrelated factors that can be used as a new variable in regression. ${ }^{8}$

Since constructs like "fishermen's relationship with extension activities" are highly generalized, multiple measures of these variables in statement forms (items) were used, and these

\footnotetext{
${ }^{7}$ Nichols, D. P. 1997. What kind of contrasts are there? From SPSS Keywords 63 (avail. at http:// www.ats.ucla.edu/stat/SPSS/library/contrast. htm).

${ }^{8}$ Batt (2004), for instance, used factor analysis to measure trust between growers and market agents. He then regressed factor scores against the (trust) variable created from factor analysis.
} 
Table 2.-Operationalization of variables.

\begin{tabular}{|c|c|c|c|}
\hline $\begin{array}{l}\text { Block 1: } \\
\text { Regions }\end{array}$ & $\begin{array}{l}\text { Block 2: } \\
\text { Fishing inputs and catch }\end{array}$ & $\begin{array}{c}\text { Block 3: } \\
\text { Socioeconomic and demographic }\end{array}$ & $\begin{array}{c}\text { Block 4: } \\
\text { Extension and R\&D }\end{array}$ \\
\hline $\begin{array}{l}\text { Which region of Al Batinah } \\
\text { do you belong to? } \\
\text { (Shinas, Masana'a, } \\
\text { Suwaiq, Khabora, } \\
\text { Barka Sohar and Saham) }\end{array}$ & $\begin{array}{l}\text { What is the power of your engine? } \\
\text { What is the length of your boat? } \\
\text { How must is your total weekly fishing } \\
\text { cost? } \\
\text { How many trips per week do you make? } \\
\text { Is it difficult to obtain fuel? } \\
\text { Is it difficult to obtain ice? } \\
\text { What is your average weekly catch? } \\
\text { How many crew members usually attend } \\
\text { a fishing tour? } \\
\text { Is the boat made of fiberglass? }\end{array}$ & $\begin{array}{l}\text { Do you keep income in-house instead } \\
\text { of sharing with the crew (if they are } \\
\text { relatives)? } \\
\text { Are you the owner of the boat? } \\
\text { Are you a partner in another fishing boat? } \\
\text { What is your age? } \\
\text { Can you read and write? } \\
\text { Are the crew your relatives? } \\
\text { Do you have another job or source of } \\
\text { income? }\end{array}$ & $\begin{array}{l}\text { Do the representatives from the Ministry } \\
\text { of Agriculture and Fisheries keep you } \\
\text { informed with new information on } \\
\text { decisions taken regarding fishing? } \\
\text { Are the government agencies quick in } \\
\text { handling your complaints? } \\
\text { Do you often exchange information } \\
\text { regarding markets, marketing, and } \\
\text { problems associated with the fishery } \\
\text { sector with representatives from the } \\
\text { Ministry of Agriculture and Fisheries? } \\
\text { Do you have a very strong relationship } \\
\text { with extension agents in your region? } \\
\text { Are you strongly involved in decisions } \\
\text { taken in research and development } \\
\text { related to the fishery sector? } \\
\text { Do you always follow the advice of the } \\
\text { extension agents? }\end{array}$ \\
\hline
\end{tabular}

Table 3.-Result of relationship with the MAF factor analysis $(n=379)$.

\begin{tabular}{lc}
\hline Factors & Factor loading \\
\hline Factor A1 & \\
Fishermen's exchange of information and cooperation with the MAF & 0.814 \\
$\quad$ Do the representatives from the Ministry of Agriculture and Fisheries keep you informed & 0.780 \\
with new information on decisions taken regarding fishing? & 0.637 \\
$\quad \begin{array}{l}\text { Are the government agencies quick in handling your complaints? } \\
\quad \text { Do you often exchange information regarding markets, marketing and problems associated } \\
\text { with the fishery sector with representatives from the Ministry of Agriculture and Fisheries? }\end{array}$ & 0.800 \\
$\begin{array}{l}\text { Factor A2 } \\
\text { Fishermen's involvement in the extension activities of the MAF }\end{array}$ & 0.432 \\
$\quad$ Do you have a very strong relationship with extension agents in your region? & 0.869 \\
Are you strongly involved in decisions taken in research and development related to the & \\
fishery sector? & \\
\hline
\end{tabular}

were rated by the respondents on an attitude measurement scale. Using principal components analysis with varimax rotation of selected items, 2 multi-item factors (having an Eigenvalue greater than 1) were identified: "fishermen's exchange of information and cooperation with the MAF"-Factor A1 and "Fishermen's involvement in the extension activities of the MAF"-Factor A2 (Table 3).

Factor A1 explains the cooperation between fishermen and the extension service agents in terms of the exchange of information and handling of complaints. On the other hand, Factor A2 explains the degree of involvement between fishermen and extension activities. The results of the factor analysis revealed that Factor A1 explained 39.626 percent, while Factor A2 ex- plained 18.508 percent of the variance (Table 4). Added together, both factors explained 58.134 percent of the variance in the sample.

\section{Checking Assumptions of Logistic Regression}

The multiple logistic regression model was first checked for outliers by examining the standardized residuals, against a condition that no more than 5 percent of the cases should have absolute values above 2 , and no more than 1 percent should have absolute values above 2.5 , and any case with a value above 3 could be an outlier (Field, 2005). Consequently, three cases that did not meet these conditions were omitted from the analysis.

The model was also tested for multicollinearity through the Variance In- flation Factor (VIF). Since logistic regression in SPSS ${ }^{\circledR 9}$ does not have the option to test for the VIF, it was done by repeating the analysis using linear regression and the VIF test (Field and Mill, 2010). Table 5 illustrates tolerance and VIF values of the variables in the final model. Since all VIF values were less than 10 with the average VIF (1.868) not substantially greater than 1 (Field and Mill, 2010) and all tolerance statistics were above 0.2 (Field and Mill, 2010), no concern regarding multi-collinearity was observed.

\section{Findings and Analyses}

Responses from a total of 379 fishermen were used after questionnaires that were either incomplete or unreliable were rejected. This figure of 379 represents 3.94 percent of the fishermen on the Batinah Coast, with an expected error level of 4.8 percent and a confidence level of 95 percent. Altogether, a total response rate of 75.6 percent was secured.

\section{Contribution of Geographical Locations}

Table 6 summarizes the results of the goodness-of-fit tests for Block 1. Entering the regions in the first block significantly $(p<0.05)$ improved the

${ }^{9}$ Mention of trade names or commercial firms does not imply endorsement by the National Marine Fisheries Service, NOAA 
Table 4.-Eigenvalue and percentage of variance of each factor (relationship with the MAF).

\begin{tabular}{lccc}
\hline \multirow{2}{*}{ Component } & \multicolumn{3}{c}{ Initial Eigenvalues } \\
\cline { 2 - 4 } & Total & $\%$ of variance & Cumulative \% \\
\hline $\begin{array}{l}\text { Exchange of information and cooperation } \\
\text { with the MAF (Factor A1) }\end{array}$ & 2.378 & 39.626 & 39.626 \\
Strongly involved with the MAF (Factor A2) & 1.110 & 18.508 & 58.134 \\
\hline
\end{tabular}

regression model, with the model Chi-squared value of 19.8 for Block 1 and $\mathrm{R}^{2}$ value of 0.09 . $\mathrm{R}^{2}$ is an indicator of the percentage of variance in the dependent variable explained by the model. Thus, "region" as the geographical variable in Block 1 explains 9 percent of the variance in fishermen's income levels. The Hosmer and Lemeshow's (H-L) goodness-of-fit test was not significant at 5 percent, which indicates that the model does not significantly differ from the observed data and predicts the real-world data reasonably well (Field, 2005).

In both the chi-squared and the H-L goodness of fit test, if the test statistic is not significant then the model represents an adequate fit, implying that the model predictions are not significantly different from observed values. However, once some continuous variables are incorporated into a logistic regression model, Pearson's chi-squared test is not effective. To avoid this potential error, the H-L test is used, which cal-

Table 5. - VIF and tolerance values.

\begin{tabular}{lcc}
\hline $\begin{array}{l}\text { Collinearity statistics } \\
\text { Variable }\end{array}$ & Tolerance & VIF \\
\hline Barka & 0.507 & 1.972 \\
Masana'a & 0.475 & 2.105 \\
Suwaiq & 0.390 & 2.565 \\
Khabora & 0.430 & 2.325 \\
Shinas & 0.388 & 2.575 \\
Sohar & 0.584 & 1.713 \\
Saham & 0.495 & 2.020 \\
Engine power & 0.271 & 3.689 \\
Boat length & 0.266 & 3.763 \\
Weekly trip cost & 0.588 & 1.700 \\
Total trips per week & 0.633 & 1.579 \\
Is it difficult to obtain fuel? & 0.704 & 1.420 \\
Is it difficult to obtain ice? & 0.836 & 1.197 \\
Avg. weekly catch & 0.772 & 1.295 \\
Number of crew & 0.714 & 1.400 \\
Use of fiberglass boat & 0.522 & 1.917 \\
Income sharing with crew & 0.782 & 1.278 \\
Ownership of boat & 0.702 & 1.424 \\
Partnership in other boat(s) & 0.709 & 1.410 \\
Fisherman's age & 0.458 & 2.185 \\
Literacy level of fishermen & 0.525 & 1.905 \\
Relationship with the crew & 0.655 & 1.528 \\
Alternative source of income & 0.791 & 1.265 \\
Exchange of information and & & \\
$\quad$ cooperation with MAF (Factor A1) & 0.731 & 1.367 \\
Strongly involved with MAF (Factor A2) & 0.794 & 1.260 \\
\hline & & \\
\hline
\end{tabular}

culates the Chi-squared statistics using a corrective procedure (Archer and Lemeshow, 2006). In stepwise logistic regression, the modal accuracy can be assessed at each step by the percentage of correctly classified observations which reveal the model's ability to correctly classify a particular percentage of cases. ${ }^{10}$ By the inclusion of geographical regions in the first step, the model correctly classified 68.2 percent of the cases (i.e., 101 cases) into their correct income level (70 cases as high income and 31 cases as low income).

\section{Contribution of Fishing Inputs and Catch Variables}

Fishing inputs and catch in Block 2 significantly improved the model $(p<0.001)$ with a Chi-square of 106.1. Table 7 examines the goodness-of-fit for Block 2. After entering the variable fishing inputs and catch, the $\mathrm{R}^{2}$ value increased from 0.09 to 0.53 . Thus the fishing input and catch group of variables explain 44 percent $(0.53-0.09=$ 0.44 ) of the variance in the fishermen's income level. The H-L goodness-of-fit test was not significant $(p>0.05)$ indicating that the model does not sig-

${ }^{10}$ See http://en.wikipedia.org/wiki/Logistic_regression. nificantly differ from the observed data. The model, with the addition of fishing inputs and catch variables, improved the classification with a correct prediction of 126 cases ( 85.1 percent), i.e., 77 cases as high income and 49 cases as low income). The outcome thus provided an improved model.

\section{Contribution of Socioeconomic and Demographic Variables}

The addition of variables describing the fishermen's socioeconomic and demographic characteristics (Block 3) improved the model significantly $(p<0.001)$ with a Chi-square of 132.7. Table 8 summarizes the results of the goodness-of-fit tests for Block 3 indicating that the model $\mathrm{R}^{2}$ rose to 0.66 . Thus socioeconomic and demographic characteristics explain 13 percent $(0.66-0.53=0.13)$ of the variance in fishermen's income level. The H-L goodness-of-fit test was not significant $(p>0.05)$, indicating that the model does not significantly differ from the observed data. The inclusion of socioeconomic and demographic variables further improved the classification to 87.8 percent of the correctly identified cases (79 high income cases, and 51 low income cases).

\section{Extension Service Contributions}

Block 4 includes the variables describing the relationship with the extension service. With Block 4 variables added, the model is now complete with significance at $p<0.001$. Table 9 summarizes the results of the goodness-

Table 6.-Goodness-of-fit tests of logistic regression model for Block 1.

\begin{tabular}{|c|c|c|c|c|c|c|c|c|c|}
\hline \multirow[b]{2}{*}{ Block } & \multicolumn{4}{|c|}{$\begin{array}{l}\text { Omnibus tests of } \\
\text { model coefficients }\end{array}$} & \multirow[b]{2}{*}{ Block $R^{2}$} & \multicolumn{3}{|c|}{$\begin{array}{c}\text { Hosmer \& } \\
\text { Lemeshow test }\end{array}$} & \multirow{2}{*}{$\begin{array}{c}\text { Cases correctly predicted (\%) } \\
\text { (High/Low income) } \\
N=148\end{array}$} \\
\hline & $\chi^{2}$ & df & Significance & $\mathrm{R}^{2}$ & & $\chi^{2}$ & df & Significance & \\
\hline Regions & 19.8 & 6 & 0.003 & 0.099 & 0.099 & $3.58 e^{-18}$ & 5 & 1.00 & $\begin{array}{c}68.2 \\
(\mathrm{H}: 70, \mathrm{~L}: 31)\end{array}$ \\
\hline
\end{tabular}

Table 7.-Goodness-of-fit tests of logistic regression model for Block 2.

\begin{tabular}{|c|c|c|c|c|c|c|c|c|c|}
\hline \multirow[b]{2}{*}{ Block } & \multicolumn{4}{|c|}{$\begin{array}{l}\text { Omnibus tests of } \\
\text { model coefficients }\end{array}$} & \multirow[b]{2}{*}{ Block $R^{2}$} & \multicolumn{3}{|c|}{$\begin{array}{c}\text { Hosmer \& } \\
\text { Lemeshow test }\end{array}$} & \multirow{2}{*}{$\begin{array}{c}\text { Cases correctly predicted (\%) } \\
(\text { High/Low income) } \\
N=148\end{array}$} \\
\hline & $\chi^{2}$ & df & Significance & $\mathrm{R}^{2}$ & & $\chi^{2}$ & df & Significance & \\
\hline $\begin{array}{l}\text { Fishing } \\
\text { Input and } \\
\text { Catch }\end{array}$ & 106.1 & 15 & 0.000 & 0.531 & 0.432 & 2.203 & 8 & 0.691 & $\begin{array}{c}85.1 \\
(\mathrm{H}: 77, \mathrm{~L}: 49)\end{array}$ \\
\hline
\end{tabular}


Table 8. - Goodness-of-fit tests for logistic regression model for Block 3.

\begin{tabular}{|c|c|c|c|c|c|c|c|c|c|}
\hline \multirow[b]{2}{*}{ Block } & \multicolumn{4}{|c|}{$\begin{array}{l}\text { Omnibus tests of } \\
\text { model coefficients }\end{array}$} & \multirow[b]{2}{*}{ Block $R^{2}$} & \multicolumn{3}{|c|}{$\begin{array}{c}\text { Hosmer \& } \\
\text { Lemeshow test }\end{array}$} & \multirow{2}{*}{$\begin{array}{c}\text { Cases correctly predicted (\%) } \\
(\text { High/Low income) } \\
N=148\end{array}$} \\
\hline & $\chi^{2}$ & df & Significance & $\mathrm{R}^{2}$ & & $\chi^{2}$ & $d f$ & Significance & \\
\hline $\begin{array}{l}\text { Socio- } \\
\text { economic } \\
\text { and Demo } \\
\text { graphic }\end{array}$ & o- & 22 & 0.000 & 0.664 & 0.133 & 3.831 & 8 & 0.872 & $\begin{array}{c}87.8 \\
(\mathrm{H}: 79, \mathrm{~L}: 51)\end{array}$ \\
\hline
\end{tabular}

Table 9.-Goodness-of-fit tests for logistic regression model for Block 4.

\begin{tabular}{|c|c|c|c|c|c|c|c|c|c|}
\hline \multirow[b]{2}{*}{ Block } & \multicolumn{4}{|c|}{$\begin{array}{l}\text { Omnibus tests of } \\
\text { model coefficients }\end{array}$} & \multirow[b]{2}{*}{ Block $R^{2}$} & \multicolumn{3}{|c|}{$\begin{array}{c}\text { Hosmer \& } \\
\text { Lemeshow test }\end{array}$} & \multirow{2}{*}{$\begin{array}{c}\text { Cases correctly predicted (\%) } \\
\text { (High/Low income) } \\
N=148\end{array}$} \\
\hline & $\chi^{2}$ & $d f$ & Significance & $\mathrm{R}^{2}$ & & $\chi^{2}$ & $d f$ & Significance & \\
\hline $\begin{array}{l}\text { Relation- } \\
\text { ship with } \\
\text { extension }\end{array}$ & 152.6 & 24 & 0.000 & 0.7637 & 0.0995 & 1.762 & 8 & 0.987 & $\begin{array}{c}92.6 \\
\text { (H: 84, L: 53) }\end{array}$ \\
\hline
\end{tabular}

of-fit tests for Block 4 indicating that adding Block 4 variables increased the model $\mathrm{R}^{2}$ to 0.76 . Thus, these variables were able to explain a further 10 percent $(0.76-0.66=0.10)$ of the variance in fishermen's income. The H-L goodness-of-fit test was not significant $(p>0.05)$, indicating that the final model does not significantly differ from the observed data. The addition of these variables improved the model's classification to 92.6 percent of the correctly identified cases (84 high income cases and 53 low income cases). The final $\mathrm{R}^{2}$ of the model was 0.76 , which means that all variables included in the model explained 76.4 percent of the variance in the fishermen's income.

\section{Individual Variables Affecting Income and Their Implication}

Having identified the major determinants as factors and subfactors, the analyses in this section reveal the significance of individual variables on fishermen's income, particularly the likelihood of an effect of a unit change in an individual variable on a fisherman's income. Table 10 illustrates the coefficient estimates of the logistic regression model. The coefficients of the predictors are in the column labeled $B$. The Wald statistic determines whether the $B$-coefficient for the predictor or variable is significantly different from zero. When found significantly different from zero, it is possible to assume that the predictor had a significant impact on income. For example, if we examine the independent variable "Fishing input and catch" in Table 10, the sign of the $B$ value $(-3.743)$ indicates a negative relationship between "Fisherman's income" and "Difficulty in obtaining ice." At the same time, the Wald statistics (4.382) and its significance $(0.036$ which is less than 0.05 or $5 \%$ ) indicate that the relationship
${ }^{1} \exp b$ is known as the Odd Ratio (OR). is significant at a $5 \%$ level of significance. The relationships and significance for other variables and sub factors can be similarly interpreted.

The value of exp- $b$, also known as the Odd Ratio (OR) is an indicator of the change in the amount of the predicted log odds of the dependent variable that would be predicted by a one unit increase (or decrease) in the predictor, holding all other predictors constant. A positive coefficient value indicates an increase in the predicted $\log$ odds of the dependent variable and vice versa.

The odds of an event are defined as the probability of its occurrence divided by the probability of its nonoccurrence (Field, 2005). The value of exp- $b$ (Odd Ratio) is interpreted in terms of the change in odds. So, if the value is greater than 1 , this indicates that as the predictor increases, the odds in favor of the occurrence of an outcome increases. For example, as an independent variable, say engine-power, increases, the chances of an increase in the dependent variable,

Table 10.-Results of logistic regression of level of income (dependent variable).

\begin{tabular}{|c|c|c|c|c|c|c|}
\hline $\begin{array}{l}\text { Groups of } \\
\text { predictors }\end{array}$ & Predictor & $B$ & S.E. & Wald & Sig. & $\exp b(\mathrm{OR})^{1}$ \\
\hline \multirow[t]{8}{*}{ Region } & Wilayat & & & 5.342 & 0.501 & \\
\hline & Shinas & -0.153 & 1.573 & 0.009 & 0.923 & 0.858 \\
\hline & Masana'a & -3.301 & 1.739 & 3.602 & 0.058 & 0.037 \\
\hline & Suwaiq & 2.315 & 1.509 & 2.354 & 0.125 & 10.120 \\
\hline & Khabora & -1.268 & 1.010 & 1.576 & 0.209 & 0.281 \\
\hline & Barka & 1.107 & 1.259 & 0.773 & 0.379 & 3.026 \\
\hline & Sohar & 2.306 & 1.740 & 1.755 & 0.185 & 10.030 \\
\hline & Saham & -1.005 & 1.214 & 0.686 & 0.408 & 0.366 \\
\hline \multirow{10}{*}{$\begin{array}{l}\text { Fishing input } \\
\text { and catch }\end{array}$} & & & & & & \\
\hline & Engine power & 0.110 & 0.062 & 3.128 & 0.077 & 1.116 \\
\hline & Boat length & 1.190 & 0.479 & 6.176 & 0.013 & 3.287 \\
\hline & Total weekly fishing cost & -0.051 & 0.018 & 8.103 & 0.004 & 0.951 \\
\hline & Fishing trips per week & 1.119 & 0.387 & 8.368 & 0.004 & 3.063 \\
\hline & Difficulty in obtaining fuel & 0.083 & 1.323 & 0.004 & 0.950 & 1.086 \\
\hline & Difficulty in obtaining ice & -3.743 & 1.788 & 4.382 & 0.036 & 0.024 \\
\hline & Average weekly catch & 20.660 & 8.108 & 6.489 & 0.011 & $9.3 \times 10^{8}$ \\
\hline & Number of crew & -1.624 & 0.781 & 4.325 & 0.038 & 0.197 \\
\hline & Use of fiberglass boat & 5.648 & 2.262 & 6.231 & 0.013 & 283.600 \\
\hline \multirow{8}{*}{$\begin{array}{l}\text { Socio-economic } \\
\text { and demographic }\end{array}$} & & & & & & \\
\hline & Income sharing with crew & -15.118 & 5.993 & 6.363 & 0.012 & 0.000 \\
\hline & Ownership of boat & -1.846 & 1.617 & 1.303 & 0.254 & 0.158 \\
\hline & Partnership in other boat (s) & 2.982 & 1.250 & 5.687 & 0.017 & 19.720 \\
\hline & Fisherman's age & 0.139 & 0.058 & 5.692 & 0.017 & 1.149 \\
\hline & Literacy level of Fishermen & 1.596 & 1.747 & 0.834 & 0.361 & 4.932 \\
\hline & Relationship with the crew & 2.164 & 2.218 & 0.952 & 0.329 & 8.706 \\
\hline & Alternative source of income & 1.244 & 1.503 & 0.685 & 0.408 & 3.470 \\
\hline \multirow{3}{*}{$\begin{array}{l}\text { Relationship with } \\
\text { Extension Service }\end{array}$} & & & & & & \\
\hline & $\begin{array}{l}\text { Exchange of information and } \\
\text { cooperation with MAF (Factor A1) } \\
\text { Strongly involved with }\end{array}$ & 3.888 & 1.516 & 6.576 & 0.010 & 48.830 \\
\hline & MAF (Factor A2) & 2.168 & 0.805 & 7.245 & 0.007 & 8.737 \\
\hline \multicolumn{2}{|l|}{ Constant } & -45.660 & 13.949 & 10.710 & 0.001 & 0.000 \\
\hline
\end{tabular}


say income, becomes higher. Alternatively, a value less than 1 indicates that as the predictor increases, the odds of the occurrence of an outcome decreases (Hutcheson and Sofroniou, 1999; Field, 2005). The exact interpretation of Odds Ratio is explained below in the section "Fishing Inputs and Catch Variables."

\section{Geographical location}

The "Wilayat" had no significant effect on the fishermen's income level (as significance (sig.) value $p>0.05$ ). Only Masana'a was found to have a near significant effect in predicting the fishermen's income level at $p<0.05$. As shown in Table 10, the odds of being in the high-income category decrease for a fisherman from Masana'a (OR: 0.037 ), as compared to the grand mean of all regions (a decrease of 96 percent). Therefore, being a fisherman in other Wilayat neither increases nor decreases the odds of being in the highincome category. This was contrary to the findings of Alhabsi (2012) which reported regional disparities affecting fishermen's output and income on the Batinah coast.

\section{Fishing Inputs and Catch Variables}

As shown in Table 10, all variables related to fishing inputs and catch significantly predict the fishermen's income levels. An odds ratio of 1.116 (alternatively, 1.116:1) 116:1 for engine power indicates that with a unit increase in engine power, a fisherman is 1.12 times more likely to be in the high-income category than the low-income category. An odds ratio of 3.29 for boat length indicates that a fisherman with a boat one foot longer than average is 3.3 times more likely to be in the high-income category than in the low-income category.

Similarly, for a fisherman, the odds of being in the high-income category go up considerably for every ton increase in his weekly catch (OR: $9.3 \times 10^{8}$ ) Similarly, a unit increase in the number of weekly trips also increases the fisherman's odds of being in the high-income category (approximately three times more than his being in the low-income category). However, the interpretation for an odds ratio less than one can be made differently. For example, an odds ratio of 0.197 for the number of crew members indicates that a unit increase in the number of crew members in a boat reduces the odds of the fishermen being in the high-income category by almost 80 percent ( 1 minus $0.197 * 100$ percent).

Previous research reveals the average number of crew on the Batinah coast to be two fishermen per boat $\left(M_{A F}{ }^{11}\right)$. This may be true as the fishing boats are small and an increase in crew size might cause inefficiencies (i.e., reduced space to store the catch) or may cause some coordination problems. Thus, this suggests that an increase in the number of crew per boat in Batinah leads to negative marginal returns for the small-scale fishermen. Therefore, any increase in the number of fishermen may result in a decrease in output, and hence, income (Canbäck et al., 2006). This means income accruing to each fishermen declines because the revenues have to be shared by more people.

Conversely, the results also suggest that fishermen might be in a diseconomy of scale situation, which can be turned around by offering bigger boats or other productive technologies. Diseconomies of scale refer to the increased per unit cost with an increase in output. In this situation, the average cost in the long run increases by a greater amount and is not proportional to the increase in the input (Canbäck et al., 2006). The positive odds ratio for boat length (3.29) discussed above supports these initial propositions and it appears that use of a larger boat is more likely to lead to greater incomes. Results also suggest that there are inefficiencies in terms of cost and number of crew.

Alternatively, odds ratios indicate that this economy of scale proposition also applies to other fishing inputs as well, e.g., availability of ice and use of

\footnotetext{
${ }^{11}$ MAF. 2002. MAF Oman study. A socioeconomic study of artisanal fishermen in the Sultanate of Oman. Arabic. Minist. Agric. Fish., Muscat, Oman, unpubl. rep. 44.
}

fiberglass boats (Table 10). It is important to note that the difficulty in getting ice is significant for predicting being in the low income category. This is an important finding because with an Odds Ratio of 0.024 , difficulty in getting ice reduces the odds of a fisherman being in the high-income category by $97.6 \%$ (or the availability of ice increases odds of a fisherman being in the highincome category by $97.6 \%$ ). A very high odds ratio for the use of fiberglass boats (283.6) indicates the potential of economies of scale obtained by using advanced technology.

\section{Socioeconomic and Demographic Variables}

Socioeconomic and demographic characteristics also contribute significantly to determining fishermen's income level. Out of seven socioeconomic and demographic variables, three were found to be significant. Two of them increased the odds of fishermen being in the high-income category. These were 1) being a partner in another boat (OR: 19.7) and 2) age (OR: 1.14). These results might indicate that partnership in another boat and fishermen's experience, particularly reflected by age, increase fishermen's income.

In contrast, fishermen who were not sharing income with the crew had decreased odds of belonging to the highincome category $(\mathrm{B}=-15.118$ and $\mathrm{OR}=0.000)$. Fishermen who could not afford to pay wages to crew members were more likely to belong to the low-income category. This simply happened because they had a low income and could not share it with the crew member, who most of the time happens to be a family member or a relative. Alternatively, those who could have afforded to pay, but did not share with the crew member, used it in meeting household expenses, rather than reinvesting it back into the business.

\section{Extension Services}

An important finding was the significance of the relationship between fishermen's income and their being involved in MAF extension activities. 


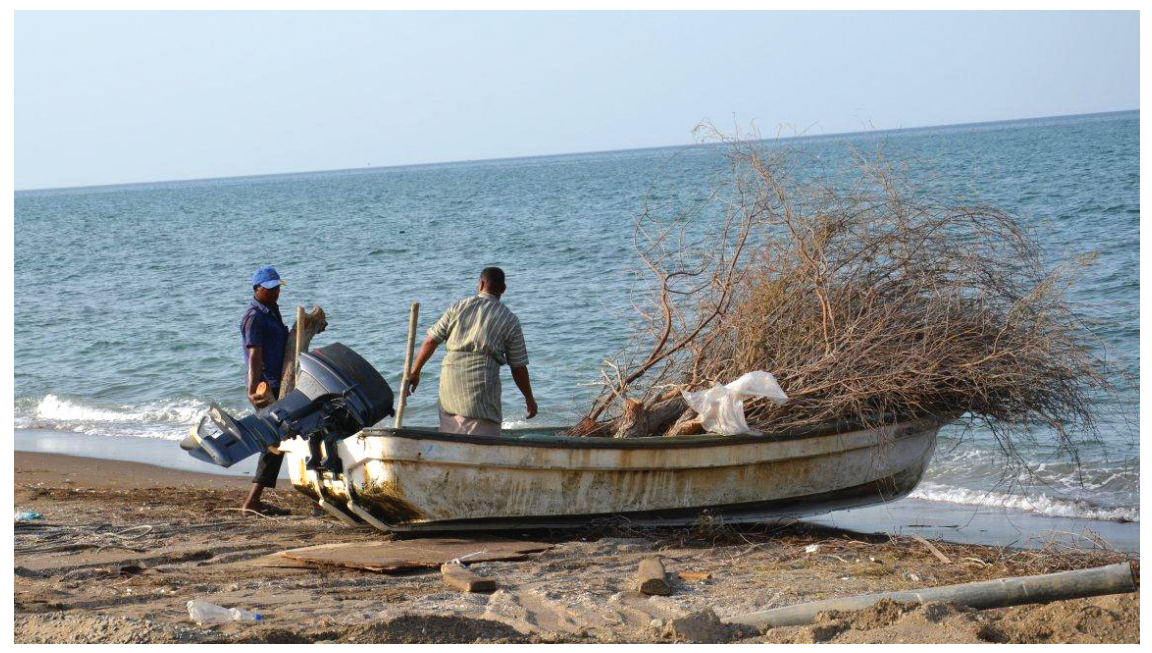

Figure 5.-Fishermen utilize shrubs and logs as artificial reefs to attract fish.

Results revealed that 10 percent of the fishermen's income was explained by having good relationships and open communication with extension services. Therefore, fishermen who have a weak relationship and poor communication with the extension service could improve their operations and financial outcomes by strengthening their relationships and communication with the service. Interactions with extension personnel lead to better knowledge of fishing areas, particularly the places where artificial reefs have been planted, awareness of better tools and technology, financial schemes of the government and the development banks, and in realizing some promising opportunities. A lack of such knowledge forces fishermen to devise their own methods to attract fish (e.g., use of shrubs and logs) (Fig. 5). Results also showed that the odds of fishermen being in the high-income category increase manifoldly (approximately 8 times as revealed by an odds ratio of 8.737) with an increase in "Fishermen's involvement in the extension activities of the MAF."

Good relations with the extension agents, involvement in $\mathrm{R} \& \mathrm{D}$, the exchange of useful information, and the good service of the extension service significantly predicted being in the high-income category (Fig. the fisheries extension service could play a positive role in encouraging improved supply-chain management practices and their uptake. This finding could lead to better extension policies and strategies for improving fishermen's income.

Fishermen's income is important to the sustainability of the fishing sector in Oman. The above findings indicate how different groups of factors can influence the fishermen's income. However, all the factors are not controllable or are controllable only to a certain extent. Oman needs to consider different alternatives to improve fishermen's income and the plight of the fishing communities. Facing similar economic and ecological pressures, communities throughout the world are looking for alternative sources of income, e.g., creating cultural tourism, establishment of eco hatcheries and aquaculture (Gupta and Pandit, 2007; Jones, 2009). Degen et al. (2010) mention how fishermen can improve their income with two possible types of diversification: earner diversification, where the fisherman has another income, and activity diversification, where someone else in the household has an income.

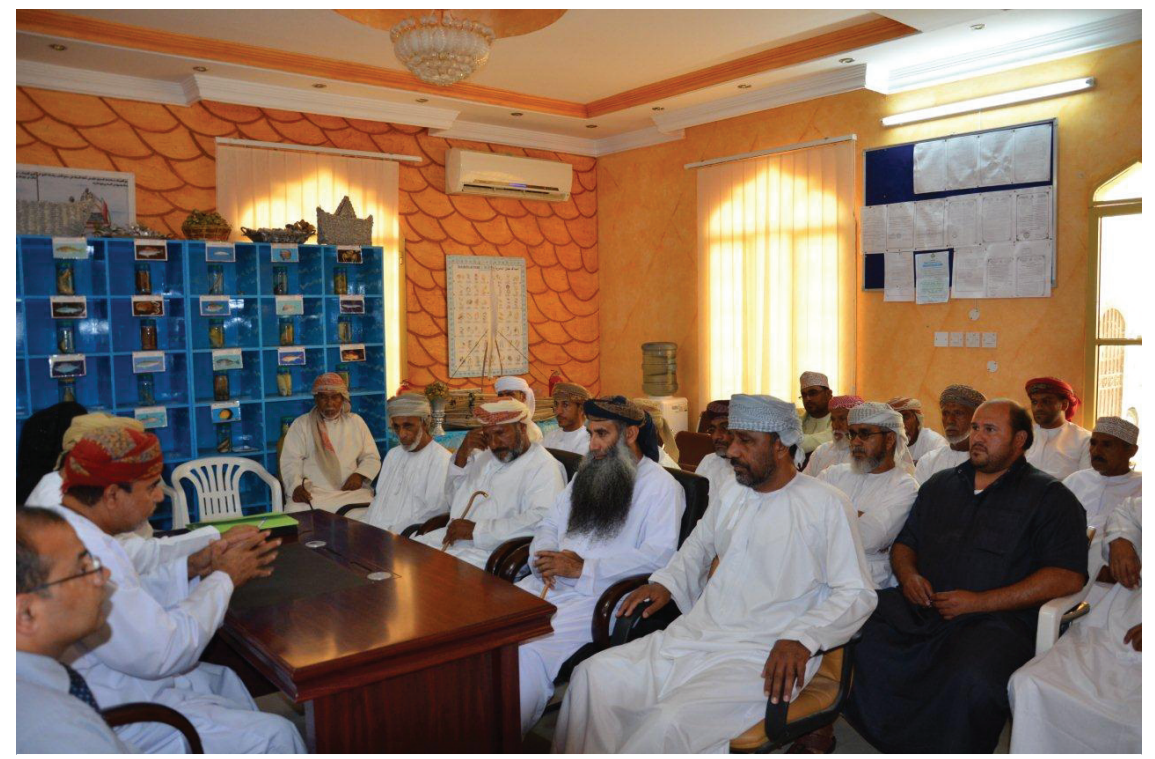

Figure 6.-Fishermen interacting with MAF officials in Liwa, Oman. 


\section{Conclusions, Policy Implications, and Limitations}

Fishing has been an important source of sustenance for fishermen in Oman. In this study, we analyzed the factors determining small-scale fishermen's income on Oman's Batinah Coast, which is home to almost 30 percent of Oman's population and almost 30 percent of the small-scale fishermen. A proportional sample of 510 fishermen was drawn using quota-cum-convenience sampling. Fishermen's income as a dichotomous variable was regressed using logistic regression analysis over four independent factors, represented by four major blocks of variables: 1) geographical region, 2) fishing inputs and catch, 3) socio-economic and demographic variables, and 4) the nature of the relationship with fisheries extension services. These factors altogether accounted for 76.4 percent of the variation in fishermen's income levels in the final model.

Contradicting some previous findings, the analysis only supported the influence of geographic region in the determination of fishermen's income to a very limited extent. However, the possibility of regional disparity cannot be completely ruled out and further studies focusing on individual differences between regions affecting fishermen's income can be undertaken. While increase in engine power, boat length, weekly catch, and numbers of weekly trips were found significant in predicting a higher income, increase in weekly fishing costs, number of crew members, and difficulty in getting ice predicted a lower income. These findings indicate the potential of awareness and training that could help fishermen in optimizing their operations and earnings.

After examining the other findings, it can be concluded that experience plays an important role in determining fishermen's income in the Batinah coast. Old and experienced fishermen could help the younger ones in learning the time-tested skills specific to the region. The study also indicates the need for crew management. The data about the number of crew and fishing costs indicate a situation of negative marginal returns, which usually occurs due to the inefficiencies associated with the "diseconomies of scale" situation.

Since fishermen's inability to share income with their crew predicts them to be in the low-income bracket, the situation potentially demands either the expansion of fishing tools and operations or a lookout for alternative employment opportunities. These opportunities could be found in related areas, e.g., artisanal fisheries-related tourism activities, aquaculture projects, or they could be as diversified as seeking alternative employment, at least for some of their family members, who until now have been engaged in unproductive fishing.

This does not seem unrealistic as fishermen elsewhere have adapted to changing economic and ecological pressures with their culture and dignity still intact. The relationship between the extension service and the fishermen and their involvement in the extension activities are important for tapping such opportunities, as they make the fishermen not only aware but also competitive and entrepreneurial.

The above findings, however, are not free from limitations which mainly arise because of the use of logistic stepwise regression analysis and the interpretation of related coefficients, and the cross-sectional nature of the study, which precludes the drawing of any definitive conclusions regarding cause-and-effect relationships. Despite these limitations, the results of the study make several contributions to our understanding of the determinants of fishermen's income.

\section{Literature Cited}

Agimass, M., and A. Mekonnen. 2011. Low-income fishermen's willingness-to-pay for fisheries watershed management: an application of choice experiment to Lake Tana, Ethiopia. Ecol. Econ. 71:162-170.

Ahmad, S., M. Jamal, A. Ikramullah, and Himayathullah. 2007. Role of extension services on the farm productivity of district Swat. Sarhad J. Agric. 23(4):1265-1275.

Alhabsi, M. S. 2012. The fisheries community of Albatinah region in Oman: a socio-economic overview. J. Fish. Sci.com. 6(3):215-223.
Al-Oufi, H. 1999. Social and economic factors influencing the emergence of collective action in a traditional fishery of Oman: an empirical assessment of three coastal fishing towns in south Al-Batinah. Univ. Hull, U.K., Ph.D. Thesis, $352 \mathrm{p}$.

E. McLean, and A. Palfreman. 2000. Observations upon the Al-Batinah artisanal fishery, the Sultanate of Oman. Mar. Pol. 24(5):423-429.

Archer, K. J., and S. Lemeshow. 2006. Goodness-of-fit test for a logistic regression model fitted using survey sample data. The Stata J. 6(1):97-105.

Batt, P. J. 2004. Incorporating measures of satisfaction, trust and power-dependence into an analysis of agribusiness supply chains. In $\mathrm{G}$. I. Johnson and P. J. Hofman (Editors), Agriproduct supply chain management in developing countries, p. 27-43. Australian Cent. Int. Agric. Res., Canberra, Australia.

Belwal, S., R. Belwal, and F. Al-Shizawi. 2012. Fishermen on the Batinah Coast in Oman. Int J. Asian Business Info. Manage. 3(1):29-49.

Canbäck, S., P. Samouel, and D. Price. 2006. Do diseconomies of scale impact firm size and performance? A theoretical and empirical overview. J. Manage. Econ. 4(1):27-70.

Christensen, A., and J. Raakjær. 2006. Fishermen's tactical and strategic decisions: a case study of Danish demersal fisheries. Fish. Res. $81: 258-267$

Davis, M. E. 2012. Perceptions of occupational risk by U.S. commercial fishermen. Mar. Pol. $36: 28-33$.

Degen, A., J. Hoorweg, and B. C. C. Wangila. 2010. Fish traders in artisanal fisheries on the Kenyan coast. J. Enterp. Commun. 4(4):296-311.

Field, A. P. 2005. Discovering statistics using SPSS: (and sex, drugs and rock 'n' roll) (2nd ed.). Sage Publ., Thousand Oaks, Calif., 816 p.

Field, A., and J. Mill. 2010. Discovering statistics using SAS. Sage Publ., Lond., 752 p.

Gupta, K., and C. Pandit. 2007. Importance of fishermen's cooperatives. Econ. Polit. Weekly 42(10):825-827.

Hendrickx, J. 1999. dm73: Using categorical variables in Stata. Stata Tech. Bull. 52: 2-8. Reprinted in Stata Tech. Bull. reprints, vol. 9, p. 51-59. Stata Press, Coll. Stat., Tex.

Hutcheson, G., and N. Sofroniou. 1999. The multivariate social scientist. Sage Publ., Lond., 288 p.

Inoni O. E., and W. J. Oyaide. 2007. Socioeconomic analysis of artisanal fishing in the south agro-ecological zone of Delta state, Nigeria. Agric. Tropica Subtropica 40(4):135-149.

Jones, B. 2009. Teetering towards economic sustainability: alternatives for commercial fishermen. J. Ecol. Anthropol. 13(1):73-77.

Judd, C. M., G. H. McClelland, and C. S. Ryan. 2008. Data analysis: a model comparison approach. 2nd ed., Routledge, N.Y., 344 p.

MAF. 2010. Annual Statistical Report. Sultanate of Oman, Minist. Agric. Fish. (MAF), Oman2010, $145 \mathrm{p}$

MONE. 2010. General census, 2010. Minist. Natl. Econ., Sultanate of Oman, 8 p.

Nielsen, J. R. 1992. Structural problems in the Danish fishing industry: Institutional and socio-economic factors as barriers to adjustment. Mar. Pol. 16(5):349-359.

Ochiewo, J. 2004. Changing fisheries practices 
and their socioeconomic implications in South Coast Kenya. Ocean Coast. Manage. 47:389-408.

Tibshirani, R. 1996. Regression shrinkage and selection via the lasso. J. R. Stat. Soc., Ser. B 58:267-288.
Tzanatos E., E. Dimitriou, L. Papaharisis, A. Roussi, S. Somarakis, and C. Koutsikopoulos. 2006. Principal socio-economic characteristics of the Greek small-scale coastal fishermen. Ocean Coast. Manage. 49:511-527.
Villareal, V. L. 2004. Guidelines on the collection of demographic and socioeconomic information on fishing communities for use in coastal and aquatic resources management. Food Agric. Organ., U.N., Rome, $120 \mathrm{p}$ 